\title{
人間・機械系の 設計 (2)
}

\section{飯 山 雄 次 *}

\section{はじめに}

前号では，人間・機械系の設計を進める上で，充分認 識しておかなければならない, システムについての概念 および，システム工学において人間・機械システムがど のような位置を占めているかについて論じられているの で今回は，人間・機械系の設計手順について概説を試み ることとする，限られた紙面のため，充分意を尽すこと 攤しいので, 主要な問題点について触れ, すでに本誌 に揭載された部分については, 引用文献として論文の末 尾に付しておくので，それらの文献を参考にして読んで 頂ければ幸いである.

\section{3. 人間・機械システムの設計手順}

\section{$3 \cdot 1$ 人間・機械システム設計の準備段階}

\section{使用の予測と目標, 目的の選定}

新しく開発されたものが，市場で成功する率は，1/5 つまり 5 品目の新製品のうち 4 品目までは, 市場に出さ れても失敗しているという米国でのデータがある. その 大きな原因として，製品そのものは悪くない，つまり八 ードウェアのデザインとしては悪くないのに，ソフトウ エアのデザインがそれについて行けなかったことが指摘 されている.

装置や機械の設計とは，実はソフトウェア—つま り，そのものの使われ方，使用のパターンという目に見 えないもの一一を創り出すことでもあるという大切なこ とを忘れていたからである：システムとしての配慮を欠 いていたからとも表現できる。

機械は, システムのゴールをかちとるために要求され

*鉄道労働科学研究所, Railway Labour Science Research Institute
るものであるとしばしば表現される．機械そのものはシ ステムの目的達成のための手段である.この原則は, 大 は宇宙開発や新幹線システムから，小は家庭用の電化製 品にいたるまで，すべてに共通することがらである.

交通機械の問題で考えれば, 個々の自動車の性能は, 狭義の機械工学的次元ではほぼ完成の域に近ついている のに，他の大きな面，現代的な使われ方の各種の側面， 車の流れ，交通計画などといった面に関するデザインが 欠如しているために，今日，世界の多くの都市に見られ るような交通の難問題と自動車の価值の低下が生じてい るといえよう。

一方，同じ交通機械でも東海道新幹線に見られる機能 性は，東京〜大阪間 3 時間というゴールに対して，シス テムが最大効率となるようにサブシステムの機能を統合 させ, かつそれらは市場の需要, 経済性, 機械の効率的 使用などを盛り込んで考えられる夕イム・スケジュール (ダイヤ)というソフトウェアから見ても, 最適となるよ うに組まれているそのシステム性, 計画性,に起因する. このシステム開発のきっかけは, 技術上の各種の成果か ら, 時速 $200 \sim 250 \mathrm{~km} / \mathrm{h}$ を営業速度とする列車が可能で ある見通しがついたからであるが，集電方式 1 つを考え てみても，架線とパンタグラフの個々の特性を向上した だけでは，高速運転時の外乱も含むダイナミックな状態 の集電能力を確保できない. システム的なアプローチに よって個々の技術とそれらを統合した機械サブシステム および人間サブシステムの体制の総合的なシステム化に よって実用システムとなったものである.

このように，システムには，はっきりした目標と使命 (mission) がある.この目標を明確にし，それにとも なう諸要件を摘出して, はじめてシステムのプランニン グ，システム・デザインなどの作業の展開が可能とな る. 人間と機械のスムーズなつながりは, システムの計 画の中でも重要なポイントである. システムを管理し， 運用するために，システムに組込まれて残った少数の人 間の責務は濃縮されてくるからである. 


\section{システムと設計体制}

J，クリストファー・ジョーンズによれば，もののデ ザイン（計画, 設計）に関する考え方が発展した過程は, 1) ヨーロッパの古い寺院などの建築に見られるような クラフト・マンの残した偉大な仕事, すなわち技巧によ る発展段階から，2）現在の工業生産方式に対応するた めに生れた製図による設計段階へと変化し, 今後は,

3 ) 装置の使用のパターン計画をデザインするシステム 設計へ進まなければ，真に要望に応えるデザインとはな らない1)としている.

これらの指摘は, 設計において単一の専門分野からの アプローチによる限界と弊害の発見であると共に, これ からの設計には, いわゆるシステム的に, 市場計画者, エンジニア, システム工学者, 人間工学者など, いろい ろなスペシャリストを含めたチームによるアプローチが 要求されることの重要性の認識でもある. 少人数, 極端 には 1 人の計画者による開発であっても, これらの要素 を満たす体制は常に要求されるものである.

\section{システムの評価の基準}

求める機能を持つシステムが, 早く安価にできること は, 誰しも希望するところである.一般にシステムを評 価する場合に必要な項目としては, 1) 性能 : 仕事を果 す能力, 2 ) 信頼度：いつまで仕事をしても故障しない, 3 ) 費用（コスト）：支払可能な金額内で入手できる, 4 ) 時間 (スケジュール)：必要な時期に入手できるこ と,および 5 ) 柔軟性 : 第一目的以外にも利用でき, 副次 的な効果も大きいことなどがあげられるが，そのシステ ムの目的・性格により, システム構成に必要な技術のレ ベルなどによって, これらの項目のおのおのについて重 点のおき方が変ってくる.たとえば, 一般産業の用に供 するものでは, 費用がとくに重要であろうし, 新しい次 元の軍事能力が付加されるようなシステムの開発では, 時間が最も問題であろう. 当初は信頼性が最重視された ものが，技術レベルの向上によって容易に高信頼性をか え得た後は, 重点が時間とか柔軟性に移るということも 起り得る. 米国の宇宙開発の初期の段階ではこの傾向が あきらかに見られる。

これらの評価項目は，さらに具体的な諸項目に分けら れるが, システムの開発の各段階において，常に必要な 評価をして所要のフィードバックが行なわれるよう，体 制を整えておかねばならない。

\section{拘束条件 (環境) の確認}

システムの計画にあたって考虑しなければならない大
きな要因として, 種々の拘束条件(環境)の問題がある. システムの計画者の意志によってはコントロール不可能 で，しかもシステムに影響を与える諸因子である.

たとえば, 宇宙空間の無重力のような現象はシステム 設計者の手によっては，いかんともし難い前提条件であ るから, システムの開発においては, この条件のなか で, 十分に機能を持つことを目標に進める必要がある.

コスト, 時間の問題も大きな制約であるし, 資材や技 術上のネックも当然問題である.

社会的な要因も大きな制約因子となる.たとえば, 1970年までに人類を月に着陸させるというアポロ計画は ソ連のスプートニク 1 号 (1958) 以来の米国の巻返し体 制の強化という事情（環境の変化）から，いくつもある はずの国家威信の高揚の手段の中からえらばれて, 強力 に進められたものである.しかし、この計画が成功した 時点では, 当時からすでに 8 年もたち, この問題をとり 巻く事情が変っていたのである. すなわち, 宇宙開発に 投じる壮大な経費は, 国家的に見ればもっと他の大切な 事業, 貧困, 飢餓の救済という地球上に残っている大き な問題の解決のためにあてるべきであるという声が大き くなり, 宇宙開発の当初のスケジュールに影響を及ぼす ようになっている.このようにシステムを取り巻き, 常 に変化を見せる「環境」条件の存在を忘れてはならな い.

\section{計画およひ設計作業の見栍り}

開発すべきシステムの内容・規模・目的に応して異な るが, 開発チームの陣容, スケシュール, 予算などのア ウトラインを事前につかんでおくことは重要なことであ る.

システムの開発計画にあたっては，無理はさけねばな らないが, システムのゴールとの関連で，必要な部門は 強化し, 必要な研究, 技術の開発は計画的, 場合によっ ては強制的促進策も講じて推進する必要が生じてくる.

米国では, 第 2 次大戦中に原子爆弾を生産するために 行なったマンハッタン計画が, 大規模な研究・開発の最 初であったといわれるが, 引きつづいて弾道ミサイル計 画など次々と大規模な開発を行なった経験から，つぎの ような指導方針がたてられている2).

たとえば, 宇宙システムの開発に際し, その研究開発 方針として，1) 第 1 要件目標と任務，2）第 2 要件又 ネジメントとその運営, 3 ) 第 3 要件設計, 製造, 検 査, 4) 第 4 要件研究, 開発, 5) 第 5 要件人材その 他などを定めている. 
無理はしないが，バランスのとれた，信頼性高いシス テムが生れるためのマネジメント戦略としての開発方針 である。

このような方針のもとに，システムの最終目標にあわ せて，現実と目標の間の距離を縮める方策として，適宜 のところに実現可能な目的を設定し，その目的にあわせ て，システム開発の細目スケシュュールを作成するわけで ある・

\section{$3 \cdot 2$ 人間・機械システムの計画}

\section{計画チームの編成}

装置を設計するということは，その装置の含まれるシ ステムの使命を具現化するための 1 つのステップであ る.

装置個々の作動は自動化されていても，プログラムの 作成, 各種のセッティング, 定形外の事態への対応な ど, 機械では困難な判断, 異常事態の処理, 保全アクシ ョンなどでは, 人間が関与することとなり，人間・機械 システムが形成される. 大型のシステムでは，機械側も それなりのシステムを形成しており, 人間側も複数で機 械と組合わされ，複合的な人間・機械システムを形成し ていることが多い.したがって, 装置計画は, 実は人間 ・機械システムの計画であるという立場を忘れてはなら ない.

人間・機械システムは, 機械サブシステムと人員サブ システムとを中心に，これに運用・管理に関するマネジ メントサブシステムなどからなる. システムの開発にあ たっては, その当初から機器優先でなく, 人員, マネジ メントなどのサブシステムの部門を担当するチームも同 時に発足させる必要がある。

機器自体の技術的開発や研究は, スタッフ部門的機能 で，その成果はシステムの展開に密接な関係はあるが， システムの計画立案のライン上に直結されるものではな い. 技術的な目新しさにひかれて歪んだシステムが組み 上がることを防ぐためである.

開発チームに加わる人間サブシステム担当のチーム は, 人間・機械インターフェースの問題, 要員の選択・ 訓練，システムの評価などに関する問題を中心に扱いな がら，システム展開に参画する.

留意すべき事項としては,

a. 機械サブシステム（ハードウェア）計画チームと人 間サブシステム担当チームは同格として，従属的立場 をとらせない。

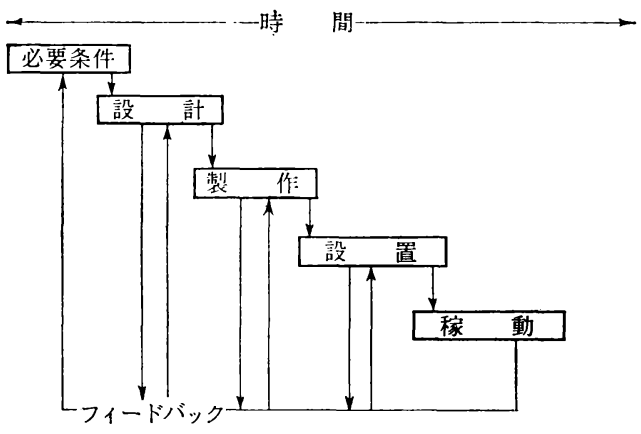

図1 システム開発段階の時間的つながりとフィードバック (Rosove)

b. 計画の当初から人間サブシステム担当チームを参画 させる．技術中心の試案ができてからでは，既決の技 術的諸条件に制約されて，好ましいシステムにならな い.

c. 既存の関連データを十分に活用して, システムの素 案作成に役立たせる.

d. 必要な実験, 研究が行なえ, 必要なデータが計画に フィードバックできる体制を作っておく．

\section{システム開発の各段階ごとの問題}

システムが開発される段階は，そのシステムの内容, 規模の大小によって差異はあるが，一般に問題が提起さ れる段階から始まって，目標を定め，現実と目標との間 に実現のための目的を選択設定し, 必要条件を分析し, 可能な構想をいくつか計画して比較評価し, 効果のあが る構想について,さらに必要な研究開発を進め, システ ムの詳細をかためて設計・試作・検討の段階を踏み，必 要なフィードバックを行なって，さらに完全なシステム にする努力が払われ，いよいよ本式にものが製作され， システムが構成されて運用される運びとなる（図 1 ).

システム開発の段階を大まかに分類すると表 1 のよう にまとめられる，この各段階ごとに人間・機械システム の次元からとらえるべき問題が多々あり，これらは人間 工学専門家の仕事となる. その作業の主なものとシステ 么開発の各段階の標準的な手順を同表の右欄に示す.

\section{システム要件の摘出}

システムの計画にあたって大切な段階は，システムの 目標を達成するに必要な使命を確認し，このために必要 なシステムの諸要件 (system requirement) を明確にす ることである.この段階は使命分析 (mission analysis) とも呼ばれる.

システムの使命からくる諸条件は，当初は概括的なも 
表 1 システム開発に必要な人間・機械系の考慮

\begin{tabular}{|c|c|c|c|}
\hline $\begin{array}{l}\text { システム開発 } \\
\text { の各段階 }\end{array}$ & 各段階の主要項目 & $\begin{array}{l}\text { 人間・機械系計画と } \\
\text { して考慮すべき事項 }\end{array}$ & 人間工学専門家の作業の一例 \\
\hline $\begin{array}{l}\text { システ公要件 } \\
\text { の明確化 }\end{array}$ & $\begin{array}{l}\text { ゴールの設定 } \\
\text { 使命の確認 } \\
\text { 運用条件の確認 }\end{array}$ & $\begin{array}{l}\text { 要員に関する要請及び制約 } \\
\text { システム運用上の制約 } \\
\text { 環境上の制約 } \\
\text { システムに組込める要員の } \\
\text { 数と質 } \\
\text { 確保できる要員の数と質, } \\
\text { 入手できる訓練設備など }\end{array}$ & 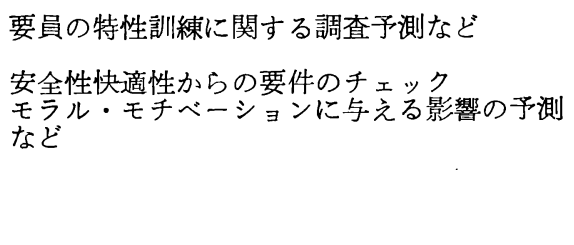 \\
\hline $\begin{array}{l}\text { システム分析 } \\
\text { とスステム計 } \\
\text { 画 }\end{array}$ & 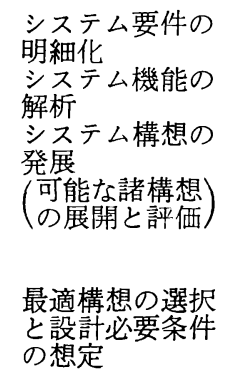 & $\begin{array}{l}\text { システム要件の分割明細化 } \\
\text { 可能な諸構想の展開と比較 } \\
\text { 検討 } \\
\text { システの機能配分 } \\
\text { 設計に関する必要な条件 } \\
\text { 人間のために必要な条件機 } \\
\text { 能分析 } \\
\text { 要員の配置と訓練の想定 } \\
\text { 人機械系としてのテスト } \\
\text { 評価の構想 } \\
\text { 他の専門グループとのトレ } \\
\text { ードオフ }\end{array}$ & $\begin{array}{l}\text { システム性能の想定 } \\
\text { ミッション・プロファイルの実施 } \\
\text { 人間と機械の役割の分担とシステ性能の変 } \\
\text { 华を各種の案について調查評価 } \\
\text { 個々性能に連する職務の分析 } \\
\text { 必要な情報と制御の種類の調査決定 } \\
\text { 機能配分に伴う要員の所定数と質の予測 } \\
\text { 訓練計画, 設備の予湘 } \\
\text { テスト評価の進め方の想定 } \\
\text { 他のサブシステムとの競合筒所の想定と対策 } \\
\text { 準備 }\end{array}$ \\
\hline $\begin{array}{l}\text { システム・デ } \\
\text { ザイン }\end{array}$ & $\begin{array}{l}\text { 予備設計（大綱 } \\
\text { の計画） } \\
\text { 設計細目 }\end{array}$ & 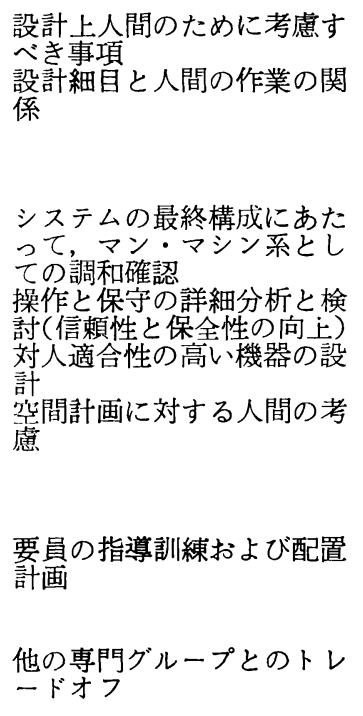 & 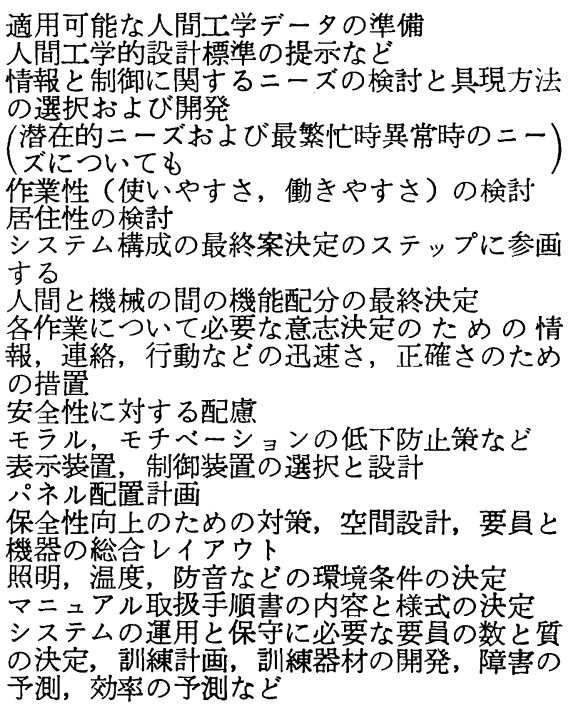 \\
\hline $\begin{array}{l}\text { システムのテ } \\
\text { ストと評価 }\end{array}$ & $\begin{array}{l}\text { 計画段階 } \\
\text { モックップ } \\
\text { 段階 } \\
\text { プロートタィプ } \\
\text { テストモデル } \\
\text { 欠かんの診断 } \\
\text { 変更の勧告 }\end{array}$ & $\begin{array}{l}\text { 人間工学的テストによる評 } \\
\text { 価 } \\
\text { テストデータの解析, 作業 } \\
\text { の解析などから設計変更へ } \\
\text { のフィードハック }\end{array}$ & 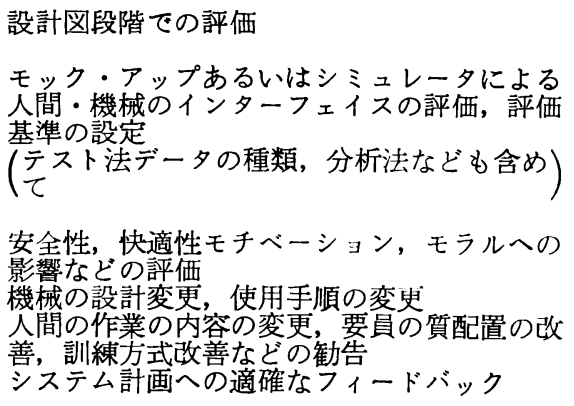 \\
\hline
\end{tabular}




\section{講座}

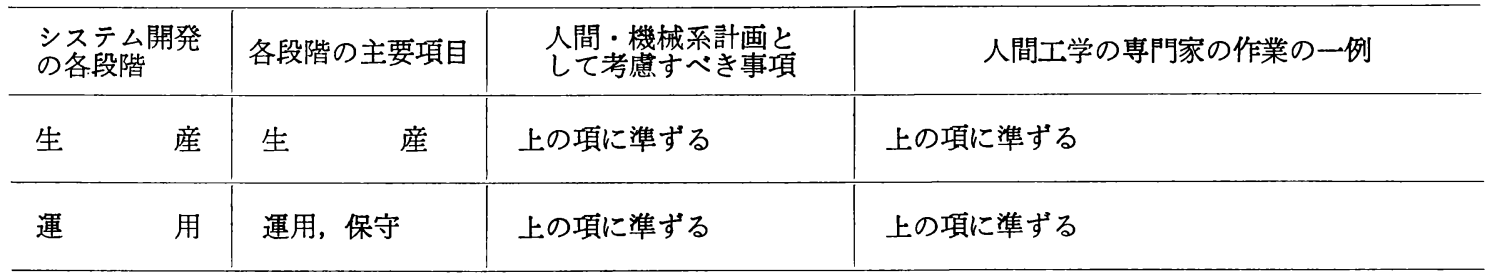

表 2 レーダーの目標探知システムにおける限界的設計要件の予借分析例（Dunlap）

\begin{tabular}{|c|c|c|c|c|}
\hline 作業項目 & 行 動 概 要 & 出 & 限界的な作業上の可変要素 & 限界的な設計要件 \\
\hline 探知と位置報告 & $\begin{array}{l}\text { 探索担当者は新し } \\
\text { い目標を探知する } \\
\text { ために, スコープ } \\
\text { を監視し探知結果 } \\
\text { を報告し, 目標物 } \\
\text { の位置を定期的に } \\
\text { 測定し, そのデー } \\
\text { タをプロット担当 } \\
\text { 者に通告する. }\end{array}$ & $\begin{array}{l}\text { 目標物の位置に } \\
\text { 関するデータ }\end{array}$ & $\begin{array}{l}\text { ○探知範囲について想定 } \\
\text { される抬がり(分布) } \\
\text { 。目檟探知作業の確率 } \\
\text { (込) } \\
\text { 。連絡に要する時間の想 } \\
\text { 羑される分布 } \\
\text { 。位置のエラーについて } \\
\text { 想される密度 } \\
\text { 。データ処理の程度 }\end{array}$ & $\begin{array}{l}\text { ○表示のデザインと配置 } \\
\text { 。探索担当者の数 } \\
\text { ○必要なまわりの照明 } \\
\text { ○連絡システムの設計 } \\
\text { 。プロット担当者との関 } \\
\text { 連を㖈慮した作業者の } \\
\text { 位置 }\end{array}$ \\
\hline 確認と追跡 & $\begin{array}{l}\text { プロット担当者は } \\
\text { 定期的な位置の報 } \\
\text { 告を受け, 位置の } \\
\text { データをプロット } \\
\text { し軌跡を求め, 速 } \\
\text { 度を評価し, 正体 } \\
\text { を確めて, 記録す } \\
\text { る. }\end{array}$ & $\begin{array}{l}\text { 目標物の追跡速 } \\
\text { 度と確認に関す } \\
\text { るデータ }\end{array}$ & $\begin{array}{l}\text { 。データプロット作業の } \\
\text { エラー確率 } \\
\text { 。データ処理の程度 }\end{array}$ & $\begin{array}{l}\text { ○表示のデザインと配置 } \\
\text { 。プロット担当者の数 } \\
\text { 。評価担当者との関連を } \\
\text { 考虑した゚ロット担当 } \\
\text { 者の位置 }\end{array}$ \\
\hline 評価と割り当て & $\begin{array}{l}\text { 評価担当者は目標 } \\
\text { 物の位置と軌跡を } \\
\text { 観察し,どの迎撃 } \\
\text { 機がどの目標物を } \\
\text { 迎撃するか を 決 } \\
\text { め, その割当てを } \\
\text { 管制官に通告する. }\end{array}$ & $\begin{array}{l}\text { 割当ての命令と } \\
\text { 評価データ }\end{array}$ & $\begin{array}{l}\text { ○評価と割当ての程度 } \\
\text { 。評価の有効性 }\end{array}$ & $\begin{array}{l}\text { ○表示のデザィンと配置 } \\
\text { 。評価担当者の数 } \\
\text { 。連絡システムの設計 } \\
\text { 。管制官との関連を考慮 } \\
\text { した評価担当者の位直 }\end{array}$ \\
\hline 航空管制 & $\begin{array}{l}\text { 管制担当者は割当 } \\
\text { 指示を受け, 迎撃 } \\
\text { データを進展させ } \\
\text { て, そのデータを } \\
\text { 迎撃機に伝え, 迎 } \\
\text { 撃機の状況報告を } \\
\text { 受け, それを評価 } \\
\text { 担当者に報告する. }\end{array}$ & $\begin{array}{l}\text { 迎撃データと迎 } \\
\text { 撃機の状態報告 }\end{array}$ & $\begin{array}{l}\text { ○進路指示の際のエラー } \\
\text { 想定される分布 } \\
\text { ○連続的な隻路指示に対 } \\
\text { する時間分布 } \\
\text { ○データ処理の程度 }\end{array}$ & $\begin{array}{l}\text { 。表示のデザインと配置 } \\
\text { 。航空管制担当者の数 } \\
\text { 。連絡システムの設計 }\end{array}$ \\
\hline
\end{tabular}


のであったり, 機器の構想が先行して, システムとして のまとまりに欠けた状態での要求事項であったりする場 合も多いまた開発途中での「評価」によって変更され ることもあり，各種の制約条件にも影響されるが，でき るだけ明確にとらえておく必要がある.

大きなシステムでは，使命をさらに検討しやすい大き さに分割して, 使命セグメント（mission segment）と し, 細部の計画, つまり機器側の機能, 要員側の行動な どの検討を行なう.このため, 使命のなかの要件をシー ケンスの機能として，グラフあるいは絵図形にして時間 経過を追って検討できるようにした使命プロファィル (mission profile) などの手法も利用する.

システムに要求される諸要件には, システムを作り上 げることを依頼した側から明確に指示されるものや， シ ステム計画の過程で明らかになる顕在的なものだけでな く，表面には現われなくとも，そのシステム構成上に必 要な潜在的な諸条件についても注意を払う必要がある.

人間サブシステム担当チームが行なうこの段階の作業 は.つぎの 3 種に大きく要約できる.

すなわち，第 1 にあげられるのは，そのシステムを使 う立場の人間が，そのシステムに対して要求する種々の 要望事項で，たとえば輸送システムに対する旅客の，あ るいは社会的要望, 電話などの通信システムに対する利 用者の要望などである。
つぎはそのシステム内で, 装置側の必要から人間に対 して課する要望事項である。

システムの機能を果すためには, 人間が何らかの形て システムの中に存在している.この人間に対して, たと えば，機械側から表示がされて，ある操作をすることを 要求する場合もあるし, 装置の故障を表示して人間に機 能回復行動をとることを要求する場合もある，自動化装 置であっても, 種々のプログラムの注入や, 各種のダイ ヤルの設定が人間に要求される.

この人間の存在が，また同時に人間側から装置側へ種 々の要望事項を出すことにもなる. それは, 装置からの 意志表示に際しては, 緊急の場合は, 反応が早く, どん な姿勢をとっていても情報が入手できる音響表示によっ て連絡してくれるようにするとか, 細かい内容がある場 合には，それに見合った情報量の多い視覚表示を使うよ らにするなどの事項である.

システムの諸要件は, システムの開 発が進むにつれ て，より明細に具体的になることが要求される.したが って, システムの諸要件は, システム開発の当初だけで なく, システム開発の各段階に存在するむのである.

\section{システムの機能配分}

システムの諸必要条件が明らかになり, システムの主 要な㗢きが決まれば，つぎはシステム・プランニングの 段階となる.この段階では，システムの概念を発展さ

表 3 機能配分の一般原則の例 (J.W. Dunlap)

\begin{tabular}{|c|c|}
\hline I . 機械に与えた方が有利な機能 & II . 人間を用いた方が有利な機能 \\
\hline $\begin{array}{l}\text { a. きまりきった仕事の反復, 計算, 大量の情報資料の } \\
\text { 蓄皘. } \\
\text { b. 大きな物理的力を迅速に与えようとする時. } \\
\text { c. 大量のデータの整理. } \\
\text { d. ある同じ特定の法則によりくだすことのできる判断 } \\
\text { を何回となく区復する時. } \\
\text { e . 環境上の制約が人間を危険におとし入れ，あるいは } \\
\text { 誤りを防しやすくしている状況下の場合. } \\
\text { f. 調整, 操作のスピードが決定的に重要な場合. } \\
\text { g. コントロールに加えられるカが厳密さを要する時. } \\
\text { h. カが長時間にわたって加えられなければならない } \\
\text { 時. }\end{array}$ & $\begin{array}{l}\text { a. 夾雑物にさまたげられたシグナル（情報）の判別 } \\
\text { （例えば, ものにおおわれた戦車を判別する場合な } \\
\text { ど． } \\
\text { b. パターンの変化する状況下でそのパターンの判別を } \\
\text { 要求される時. } \\
\text { c. 種々雑多の入力の間に判別が要求された時. } \\
\text { d. きわめて発生頻度の低い事態に対処して, 判断が望 } \\
\text { まれる時は, 適応性のある人間の方がよい. } \\
\text { e. 帰納的推理力の要求される問題の解決を要する時. } \\
\text { f. 不測の事態の発生が予期され, それを探知し, 情報 } \\
\text { の報告を望をれる状況では, 人間を用いることがよ } \\
\text { い. }\end{array}$ \\
\hline
\end{tabular}




\section{講座}

せ，システムの使命を果すために考えられるいくつもの システム構想案を作り,これを検討する作業を行ない, 基本的な設計条件を固めることとなる.

この段階では，そのシステムが果すべき機能のすべて を判断して，それぞれの機能を人間の作業と機械の作業 に割りあてることを考えねばならない，人間と機械では その能力にそれぞれ長所短所があり，おのおの独特の特 性や限界がある $(2 \cdot 2$ 参照). これらにもとづいて, シス テムの果すべき仕事のそれぞれについて，人間対機械の 能力・限界・コストの差を考虑するわけである。これを システムの機能配分 (allocation of system functions) といっている.

機能配分の一般的原則は表 3 に示す通りであるが，対 象となるシステムによって細部は異なる3゙.

\section{人間の作莱環境の条件}

そのシステムでは，人間の安全性に対して問題はない かのチェックも重要である. 放射能, 高電圧, 高低温, 高低生, 酸素の不足, 異常な $\mathrm{G} な と ゙$ 考虑すべき多くの要 素がある. 図 2 に環境条件の一般的数值を示す.

環境条件が，人間に対していちじるしく問題であれ ば，前記の機能配分の一般原則で間に与えることが好 ましい作業でも，それが必要な作業ならば，これを機械 側で処理する方策を考え好ばならない. 常時, 劣悪な環 境下におかれていなくても，その発生の可能性があり， かつシステムとしてもクリティカルな条件の場合に発生

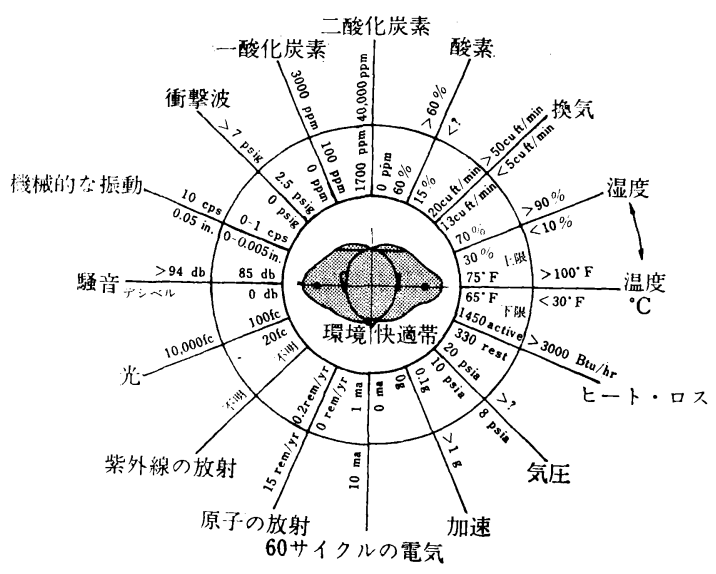

図2 快適な環境条件 (Mcfarlaub)
するようであれば，十分な検討が必要である.

作業環境の詳細については，専門書を参照されたい.

\section{要員の制約}

許容される要員の数と資質 : 航空機や宇宙船のよう に，そのシステムに組込むべき要員の数が決定的に重要 な場合がある，また一般の産業関係のシステムでは，運 転コストの関係から要員の数が限定されることも多い. システムが平常の運用下におかれている時と異常事態の もとでは作業に大きな差がでるのが普通であるが，その いずれの場合でも要員の制約の中で考えねばならない. またこれらの要員の適性, 心身の機能, 体格, 寸法, 体重 などの要望についても, システム構成上無視できない.

確保できる要員の数と資質 : 要員に対する希望条項が もし極端にきびしくなると，それに見合う素質を持った 要員を獲得することの難易が問題となる. 平常時は楽で も異常事態に対処するには難かしい能力が求められる場 合も，条件としてはきびしくなる. システムの計画に際 して人間に与える機能の配分などを最適にして，人間に 対する希望条項を緩和しておくのも，人間サブシステム 担当部門の仕事である.

\section{訓練設備の活用}

システムの完成時には, 要員は十分な技価を有してお り，ただちに作業に入れることが必要である.このよう にシステムの機械サブシステムの作業の進捗と平行し て，要員が十分な技価に達するような訓練器材を開発し 設置し訓練の想定をたてることも，人間サブシステム担 当部門の役割である.

大型のシステムで, 監視すべき表示や対応動作として 操作すべき機器の種類や数が多い場合は, 特にフルスケ 一ルの訓練装置が効果的で，動的機能まで含まれたシミ エレータの設備が最も望ましい。

シミュレータの計画にあたっては，作業者が技能修得 の過程上もっとも困難でかつ時日を要するような項目に 重点をおいて機能と形態を決定すべきである.

\section{参考文献}

1) J.クリストファー・ジョーンズ；デザイン方法論 セミナ一, 工芸ニュース，38-2, 丸善

2 ) 山本通隆; NASAのマネジメント, オムロンテク ニクス, Vol. 10-3, 1970

3) J.W.ダンラップ; ヒューマン・ファクタ・エンジ ニアリングの調査・研究方法と計画, 工芸ニュース, Vol. 32-4, 1964 